Dragana V. Stanimirović

Faculty of Special Education and Rehabilitation University of Belgrade

\section{Luka R. Mijatović}

Faculty of Special Education and Rehabilitation University of Belgrade

\section{Sanja M. Dimoski}

Faculty of Special Education and Rehabilitation

University of Belgrade
УДК: 159.922.8::-056.262 Ориіинални научни рад Примљен: 28. 08. 2014

\title{
IDENTITY CRISIS IN THE YOUNG BLIND AND THEIR IMPRESSION OF PEER SUPPORT
}

Identity crisis was understood here as a developmental difficulty on the road to maturation. Little empirical data are available concerning identity crisis in adolescents with visual impairment, while the results of studies of social peer support remain contradictory. This has motivated us to examine the specifics of identity crisis in the blind in comparison to their sighted peers. Moreover, by using comparative analysis, we also wanted to give a contribution to a better understanding of social peer support and its relations with identity crisis in the young blind. 32 blind and 32 sighted adolescents were interviewed and given a checklist of identity crisis indicators. The results demonstrated that, comparatively, the blind participants' identity crisis was more intense and more often delayed, while their assessment of all three forms of peer support was lower. Moreover, the content of perceived emotional and informational support was similar while the content of perceived tangible peer support was completely different from that in the group of the sighted adolescents. Finally, perceived tangible peer support correlated significantly with identity crisis only in the group of the blind youth. Therefore, the findings underline the special importance of perceived tangible peer support to the young blind.

Key words: blindness, adolescence, identity crisis, perceived peer support

\section{Introduction}

Adolescence is the most turbulent period of life (Golombek \& Marton, 1992; Marcia, 1966; Medovy, 1964) that has a crucial importance for identity formation (Klimstra, Hale, Raaijmakers, Branje, \& Meeus, 2010; Waterman, 1982). Findings about the frequency of identity crisis, understood as a developmental difficulty on the road to maturation (Offer \& Offer, 1975; Offer \& Schonert-Reichl, 1992), are con- 
gruent with that. Adolescence is also a time when peer group play an important role (Freeman \& Brown, 2001; Laible, Carlo, \& Raffaelli, 2000; Batgos \& Leadbetter, 1994; Berndt \& Ladd, 1989; Burke \& Weir, 1978; Collins \& Repinski, 1994; Greenberg et al., 1983; Solomon \& Grunebaum, 1982; Steinberg \& Silverberg, 1986, according to Wilkinson, 2004), which is more important than that of parents (Blos, 1979; Coleman, 1961; Douvan \& Adelson, 1964, according to Wilkinson, 2004).

\section{Theory of identity formation}

According to Erikson's phase-theory of development of identity, each of the eight phases of life cycle has its specific developmental tasks, and therefore each represents a potential crisis situation. The fifth phase of identity formation (13 - 18 years of age) is the most turbulent one, because all previous bad solutions intersect in it. "To the extent that there are developmental problems in one or more of the first four stages, the adolescent may be hindered by feelings of mistrust (a lack of trust), shame and doubt (the alternatives to autonomy), guilt (the alternative to initiative), and/or inferiority and futility (the alternatives to industry)" (Moshman, 2005: 81). A person has to overcome a series of conflicts in order to achieve an appropriate identity. Identity is the answer to the question «Who am I?"; therefore, it is a stable feeling of internal identity with the self (Erikson, 1979). Erikson relates the term «identity crisis» to the phase of identity formation, and by that term he implies a confusion of roles or a necessity of resolution of the original failure in the formation of a stable identity. "By crisis, he does not mean an impending catastrophe, but rather a critical turning point in the life history of an individual, in which development can only move forward by taking a new directional course" (Kroger, 2003: 207). Erikson concludes that the subjective feeling of confusion, with the symptoms of the loss of the sense of life and continuity, represents in some patients a more pronounced form of normal developmental process. He shifts the emphasis of psychoanalysis from pathology to healthy functioning (Kroger, 2001).

There is an alternative view of development, not understood as passing through phases, but seen as lifelines. It is not deemed necessary to pass one period before entering the next one; instead, you can take alternative routes. Marcia (1966) offers a view of identity formation, centered around two dimensions: exploration (of developmental alternatives in various domains) and commitment (selection of alternatives and engaging in activities). On the basis of these two dimensions, adolescent identity can be classified in four different types: diffusion (a less adaptive identity status); foreclosure; moratorium; and achievement (the most adaptive identity status) (Marcia, 1966; Klimstra, Hale, Raaijmakers, Branje, \& Meeus, 2010).

\section{Empirical findings about identity crisis}

The results of some studies revealed that $20 \%$ of the young had problems and needed help, while others passed through adolescence without turbulences (Offer \& 
Offer, 1975; Offer \& Schonert-Reichl, 1992). Golombek and Marton (1992) used the term «turmoil» to denote typical changes in adolescence. They found it in $42 \%$ of adolescents but it did not have the characteristics of impairment or impoverishment, as was the case with $24 \%$ of adolescents who represented the pathological population and whose development had not been going smoothly, as was the case with those $34 \%$ who did not reveal signs of turmoil in adolescence. While signs of clinical depression were found in $20 \%$ of adolescents, mood swings, withdrawal, changes in eating and sleeping, difficulty concentrating, reduced engagement in reinforcing activities, fatigue, and irritability were frequent and represented a part of normal adolescent behavior (Birmaher et al., 1996b, according to Koenes \& Karshmer, 2000). These and similar phenomena have been described in the relevant literature as indicators of identity crisis )Kondić, 1997).

\section{Blindness and identity crisis}

The crisis of the loss of sight is especially turbulent in the phase of identity formation, so that the question "Who am I now and what my future will be?" is imposed in a much more difficult manner. These questions are also difficult for those who were born blind or for those who had lost sight in childhood. The outcome depends on a successful resolution of conflicts from previous phases as well as on events happening in this phase (Rosenblum, 2000). Although a blind baby expresses an innate need for contact, the attachment process can be delayed (Fraiberg, 1977; Warren, 1994). A blind baby not accustomed to obtaining consistent and reliable stimuli from its parents will not seek contact with them (Recchia, 1993, according to Lappin, 2006). In this case, theory by Erikson suppose that the baby comes out of the first phase of identity development with a basic feeling of insecurity. During the second year, many of these children fall back in motorics and conceptual development, not only because of sensomotoric deprivation but also because of inappropriate practicalsituational communication (Ihsen, Troester, \& Brambring, 2010; Loots, Devisé, \& Sermijn, 2003; Recchia, 1997). Parents often overprotect blind children (Cimarolli, 2006; Cimarolli, Reinhardt, \& Horowitz, 2006; Pinquart \& Pfeiffer, 2011). Hall \& McGregor's follow-up study (2000) has noted a comparatively stronger tendency to solitary play, socializing in smaller groups, and more interactions with adults. Somewhat similar were the findings of Sandberg, Björck-Ĺkesson \& Granlund' study (2004), based on adult respondents' memories. Thus, blind children often have no opportunity to mature through play with their peers. Social play may give rise to feelings of frustration, rather than self-efficacy and independence, which characterize the social experience of typical children (Celeste \& Kobal Grum, 2010).

A situation when investments in the intellectual development of blind children surpass by far investments in their other developmental aspects in adolescence leads 
to disproportions between intellectual maturity (reached at the same time as their peers) and social maturity (they fall behind significantly) (Stanimirović, 2007).

Chapman (1978) states that it is important for a blind adolescent to be aware that his/her friends can do something easily, while he/she cannot, and therefore to develop, for example, an excellent memory for sports results or something else, whereby he/she might win respect and experience success in the activities which are normal for his/her age.

Low scores on all self-concept scales, and the lowest ones on the identity scale, demonstrate that visually impaired adolescents undergo a serious identity crisis. (Meighan, 1971). Some comparative studies of the self-concept of adolescents with and without visual impairment demonstrate that the former have a comparatively more negative self-image (Beaty, 1991; Beaty, 1992; Lopez-Gusticia, Pichardo, Amezcu \& Fernandez, 2001), while some others have found similar profiles (Head, 1979; Huurre, Komulainen \& Aro, 1999), or even higher scores of visually impaired adolescents on some self-concept scales, which can be explained by the effect of resilience (Lifshitz, Hen \& Weisse, 2007).

\section{Peer relationships in adolescence}

Peers can strongly influence an adolescent's development of identity. They, rather than parents, become more suitable role models and a more convenient source of self-affirmation. Peers not only provide adolescents with a major support structure, but also offer an environment in which they can develop feelings of self-worth (Seiffge-Krenke \& Shulman, 1993, according to Opperman \& Alant, 2003). Young adolescents need a growing social network to develop social competencies (Colarossi \& Eccles, 2000; Cotterell, 1996). An adolescent group has identical ways of behavior and common attitudes and values, and it encourages the conquest of independence and separation from parents through devaluation of parental values (Feldman \& Quatman, 1988; Stewart, Bond, Mcbride-Chang, Fielding, Deeds, \& Westrick, 1998). Simultaneously, the importance and the level of perceived social support are changed as well. Namely, support previously offered by parents is during adolescence much more offered by peers (Degirmencioglu et al., 1998, according to Colarossi \& Eccles, 2000; Levitt, Guacci-Franco, \& Levitt, 1993).

Friendship in adolescence becomes more intimate than in childhood and more similar to that of adults. While parental giving and child receiving dominate the parent-child relationship, the relationship that dominates in friendship is cooperation and equality (Piaget, 1965; Youniss, 1980, according to Laible, Carlo, \& Raffaelli, 2000).

\section{Peer relationships of the young blind}

The young blind must accomplish the developmental tasks of separation from their parents and gaining independence. Just like all other adolescents, they too want 
to be similar to their peers and not special or different (Kef, 2002). However, the limitations imposed by impairment (directly, or indirectly - through environmental reactions) put into question the equality with peers, which creates in them a conflict between the need for independence and the need for a concrete social support. The unpredictability of the behavior of others, stigmatization and the absence of attractive appearance increase the risk of social rejection and drift into an outsider position.

Eye contact, gestures, facial expressions and contextual information are some important facets of social interactions that are influenced by vision (Kekelis, 1992). Blindness is a communication barrier (Fraiberg, 1977) that disrupts the flow of intersubjectivity (Roch-Levecq, 2006). Perhaps the most difficult aspect of the development of social-skills of visually impaired teenagers is the discovery of nonverbal communication, including body language and facial expressions (Wolffe, 2000). Thus, the impossibility to use visual signs puts limits to their social behavior.

Booth (2000, according to Murugami, 2009) argues that disability in a sociocultural context can be defined as a barrier to participation of people with impairments or chronic illnesses arising from an interaction of the impairment or illness with discriminatory attitudes, cultures, policies or institutional practices. Children with disabilities appear to be more prone to social isolation because of fewer positive responses to their initiatives for social interaction or because of their less frequent attempts to engage in social interactions (Celeste \& Grum, 2010, according to Papadopoulos, Metsiou \& Agaliotis 2011). Some findings reveal that there is a significant risk for children with disabilities to be excluded from ordinary activities (King, Law, King, Rosenbaum, Kertoy, \& Young, 2003). Huijgevoort (2002) concludes that some studies have pointed out to the social isolation of adolescents with visual impairment, while some other authors have not revealed differences in comparison to sighted adolescents. A review of the results of these studies revealed that adolescents with visual impairment had fewer friends (Huurre \& Aro, 2000; Kef, 1997; Kef, 2002; Lieberman \& Stuart, 2002, according to Robinson \& Lieberman, 2004; Rosenblum, 1998), worked harder than sighted adolescents to maintain friendships (Sacks \& Wolffe, 1998 according to Kef, 2002), and less often had many friends and dating experiences (Huurre \& Aro, 1998 according to Kef, 2002). However, adolescents with visual impairment were successful in establishing and maintaining reciprocal relations with their best friends, but the latter were slightly older than them (Rosenblum, 1998).

Kef (2002) remarks that researchers should focus their attention on the quality and content of peer relationships and peer support. In this way, Skär (2003) carried out a study that included adolescents with restricted mobility. She found that their relationships to peers, which were both strained and insufficient, took place primarily in school. 
Rosenblum (2000) found that adolescents with visual impairment were often outsiders in the hierarchy of the school culture, but they had experienced firsthand the benefits of having friends. After their parents, the next strongest source of practical and emotional support was their friends (Kef, 1997). Kef, Hox, \& Habekothe (2000) have not found significant differences in perceived peer support between adolescents with and without impaired sight. They quoted Sacks \& Wolffe $(1997,1998)$, who had found that the students with visual impairment who lived independently received more support than sighted students, but also had fewer friends who could provide support to them. A Finnish study has found that peer support to adolescents with visual impairment better predicted high self-esteem, high well-being, and less loneliness than parental support did (Huurre \& Aro, 1998 according to Kef, 2002), while a Dutch study has found that perceptions of peer support had positive associations with adjustment and well-being of adolescents with impaired vision (Kef, 2002). Therefore, both studies have called attention to the importance of social peer support.

\section{THE AIM OF THE STUDY}

The study aimed to examine whether the young blind and the young sighted significantly differ in the intensity of identity crisis and the level and content of particular forms of peer support. Additionally, the study aimed to test whether the intensity of identity crisis correlates significantly with the level of particular forms of peer support.

\section{Method}

\section{Participants}

The sample consisted of 32 participants of the experimental group (blind youth) and 32 participants of the control group (sighted youth).

The criteria of participant selection were the following:

- aged between 14 and 26 years;

- do not have another impairment, except blindness in the experimental group;

- live in the complete family of their origin;

- no family member has serious personal, marital or familial problems.

The additional criteria of selection in the experimental group were:

- blindness according to the definition of the World Health Organization ;

- sight lost before the 11th year of age.

The groups were entirely matched on the following socio-demographic characteristics: sex (20 boys and 12 girls), age (the average age 239 months), professional status (15 elementary and secondary school students; 7 university students; 4 employed and 6 unemployed), mother's education ( 7 with elementary school, 19 with 
high-school and 6 with university), number of children in the family (5 with one, 24 with two and 3 with three) and city-village distribution ( 26 from a city and 6 from a village).

We included participants older than 18/21 years in order to examine delayed identity crisis. The blind participants had all lost sight before the 11th year of age, which means that they did not have an ongoing vision loss crisis that it could coincide with potential identity crisis.

\section{Instruments}

The instruments used to collect data were:

1. A questionnaire of basic data;

2. A checklist of identity crisis indicators

3. Interview of peer support

The questions contained in the first instrument related to socio-demographic variables and personal, marital or familial problems of family members. These data were used for the final formation of the sample and matching of the groups.

The starting basis for creation of our checklist of identity crisis was Kondić's list (1997), with the following indicators of identity crisis: dissatisfaction with appearance, depression, unsociability, frequent conflicts with parents, general insecurity, the feeling of absurdity of life, the need to change a body part, suicidal tendencies, insecurity in peer communication, insecurity in relations with the opposite sex, noticeable school failure, fits of anger, loss of appetite, overeating, nightmares, abuse of alcohol, and suicide attempt. We omitted the last two indicators because they belong more to pathological than to normal developmental process. We retained the indicator "depression", because the word usually denotes dysphoria. On the other hand, we included the indicator "loneliness" which Erikson, among others, mentions as a characteristic of identity crisis.

The newly created list was then administered within a pilot-study to 50 high school and university students who were also given a possibility to supplement the list with some other phenomena that they deemed relevant. In that manner, we created the final list with the following 18 items: noticeable school failure, insecurity in peer communication, insecurity in relations with the opposite sex, general insecurity and/or shyness, dissatisfaction with appearance, the need to change a body part, withdrawal, loneliness, depression, nightmares, loss of appetite, overeating, fits of anger, frequent conflicts with parents, the feeling of life's absurdity, suicidal tendencies and ideation, demonstrations that the respondent can earn his/her life, and incidental behavior in school/at work.

The checklist of identity crisis was administered to the participants as "A list of the phenomena that characterize the majority of the young". Each participant was 
asked if any of the phenomena was present in him/her, and if so, what was the age when it had occurred/had started.

The interview of peer support begun by a three-point assessment scale :0 - not at all; 1 - a little; 2 - a lot. With this scale, the respondents assessed how much each modality of support (tangible, informational, emotional) was given to them by their peers. Moreover, they were also given a possibility to present reasons for their assessment. After that, they were asked to describe the way their peers gave them tangible, informational and emotional support and help.

\section{Procedure}

Data on possible respondents in the experimental group were given to us by the Union of the Blind, while possible respondents in the control group were identified by us through colleagues and friends. Each of the respondents (or their parents) was asked for consent to participate in the study.

The study was carried out individually. Each of the blind participants had a copy of the instruments written in Braille (The checklist of identity crisis indicators and a three-grade assessment scale of social support) and so they could either read the items themselves or have them read to them by the examiner, who also recorded the blind respondents' answers. The same procedure was also applied to the sighted respondents, who were given printed copies of the instruments. All interviews, in both groups, were audio taped.

\section{Results}

\section{Intensity of identity crisis}

In order to test the significance of group differences of the self-assessed intensity of identity crisis we applied univariate analysis of variance.

Table 1.

\begin{tabular}{|l|c|c|c|c|}
\hline & Experimental group & Control group & & \\
\hline & $\mathrm{M}$ & $\mathrm{M}$ & $\mathrm{F}$ & $\mathrm{p}$ \\
\hline Intensity of identity crisis* & 25.44 & 22.28 & .935 & 0.03 \\
\hline
\end{tabular}

$* \mathrm{p}<0.05$

${ }^{1}$ Intensity of identity crisis - The difference between the experimental $(\mathrm{N}=32)$ and the control group $(\mathrm{N}=32)$

The results shown in Table 1 demonstrate that the differences are statistically significant. The young blind, when compared to their sighted peers, experience much more intensely their identity crisis. 


\section{Frequency of delayed identity crisis}

Group differences of the delayed identity crisis were tested through comparison of the proportion of appearance of the indicators of identity crisis at the ages of 1420 and 21-26 years.

The blind young related appearance of the indicators of identity crisis to the age of 14-20, and/or 21-26 years in the ratio 3:5, while the ratio of the sighted young was $5: 1$.

\section{Level of perceived peer support}

In order to test the significance of group differences of the level of particular modalities of perceived peer support we applied univariate analysis of variance.

Table 2.

\begin{tabular}{|l|c|c|c|c|}
\hline & Experimental group & Control group & & \\
\hline & $\mathrm{M}$ & $\mathrm{M}$ & $\mathrm{F}$ & $\mathrm{p}$ \\
\hline Tangible peer support* & 1.81 & 2.34 & 6.074 & 0.017 \\
\hline Informational peer support* & 2.03 & 2.53 & 6.369 & 0.014 \\
\hline Emotional peer support* & 2.13 & 2.53 & 4.148 & 0.046 \\
\hline
\end{tabular}

${ }^{*} \mathrm{p}<0.05$

${ }^{2}$ Differences of the levels of particular modalities of peer support between the experimental $(\mathrm{N}=32)$ and the control group $(\mathrm{N}=32)$

The results shown in Table 2 demonstrate that all differences of the levels of particular modalities of peer support are statistically significant. All modalities of support were significantly weaker in the experimental than in the control group.

\section{The content of perceived peer support}

Qualitative analysis made it possible to discover the content of particular modalities of perceived peer support. We analyzed similarities and differences between the examined groups.

In their descriptions of tangible peer support, the blind respondents exclusively started from their special needs. Typical answers were: "when I can't do something by myself", "when taking me in or out", "If I asked for help, here, in the village, they would take me with them, maybe they would read me something as well, but I don't do that", "my university colleagues approach me sometimes offering their help, but they don't know how to do it, and so, I don't expect it". Descriptions of the respondents from the control group concern actions such as helping in learning, whispering, getting to know a boy or a girl, repairing a car or a computer, lending money and clothes, etc. 
As for informational peer support, the respondents from both groups mentioned current events (a concert or an exam, etc.), as well as advices on problems in love, in school or at work. Besides, the blind respondents spoke about exchanging information with blind friends regarding the means that made their lives easier (speech programs for mobile phones, etc.).

Finally, regarding emotional peer support, the respondents from both groups mentioned "closeness", "intimacy", "confidence", and "a shoulder to cry upon". The categories of responses, and even of words, were the same.

\section{Correlations of the intensity of identity crisis and the level of peer support}

In order to test the correlations between the intensity of identity crisis and the level of particular modalities of peer support, we calculated Pearsons's correlation coefficients.

Table 3 demonstrates the correlations between the intensity of identity crisis and the level of peer support in the experimental group. We can see that only the correlation of the identity crisis score with tangible support score is significant.

Table 3.

\begin{tabular}{|l|c|c|}
\hline & \multicolumn{2}{|c|}{ Intensity of identity crisis } \\
\hline & $\mathrm{R}$ & $\mathrm{p}$ \\
\hline Tangible peer support* & -0.397 & 0.024 \\
\hline Informational peer support & -0.239 & 0.118 \\
\hline Emotional peer support & -0.168 & 0.359 \\
\hline
\end{tabular}

${ }^{*} \mathrm{p}<0.05$

${ }^{3}$ Correlations between the intensity of identity crisis and the levels of peer support in the experimental group

\section{Discussion}

\section{Concerning the intensity of identity crisis}

Results support our expectations that the question "Who am I now and what my future will be?" is much harder for blind than for sighted adolescents. We noticed a comparatively greater discrepancy between the internal lines of their development, as well as a discrepancy between external demands and their abilities to cope with them. Moreover, the group of the blind young would have a more intense identity crisis than the group of the sighted young because there was a greater possibility that the blind respondents had not resolved their conflicts from the previous phases of development. When explaining his results about the weaker self-concept of blind adolescents, 
Meighan (1971) said that the danger of fixation of a negative identity, produced by a disparity of the physical and psychic development in blind adolescents, is real. We think that one should not generalize, but rather say that a blind person must overcome comparatively more internal and external conflicts in order to achieve an appropriate identity.

Some factors, such as delayed attachment process, poor practical-situational communication and experiences with peers, and parental overprotection are risk factors that produce conflicts in early stages of development. The discrepant lines of development mentioned by Stanimirović (2007), the competition with peers in adolescence that Chapman (1978) wrote of, conflicts between the demands of blindness and the developmental demands of adolescence, and uncertainty about the future, can reinforce identity crisis in the young blind. All of these can be reasons why the score of identity crisis in the group of the blind was higher than that in the group of the sighted.

\section{Concerning the frequency of delayed identity crisis}

One of the factors that affect a delayed onset of the identity crisis more frequently in the experimental group than in the control group (i.e. in the majority of the young blind) is probably their dependence on others. Instead of encouraging their independence, many of their parents overprotect them. Blindness can be a "good" excuse to keep a child in the state of dependency. Moreover, doubts about the future can endanger the continuity of the blind youth whose balance, endangered by more conflicts, needs more time to be established.

\section{Concerning the level of perceived peer support}

Prejudices, stigmatization, discrimination and other factors impose limits to social interaction and by the same token impose limits to possible social support too. We assumed that this would affect informational and emotional support, which was confirmed.

We expected that the young blind would receive a stronger tangible support from their peers because they needed it more and that, at that age, they were probably frequently aided precisely by the peers. However, the lowest arithmetical mean was observed precisely in perceived tangible support in the blind. In fact, we do not know how strong that support really is. Some studies have revealed a stronger received support, while some others have not found differences in received peer support to adolescents with and without visual impairment. Kef (2002) was right in saying that there could be a difference between perceived and received social support. Regardless of whether it is we who overestimate it or they who underestimate it, it is important to point out that the young blind, when compared to their peers, had the impression of 
receiving less tangible support from their peers. A reason for this impression can lie in a conflict between the need for independence (that includes the need for equality) and the need for tangible support - a conflict because of which they do not demand, refuse or unconsciously deny peer support. A confirmation of this can be found in their descriptions of tangible peer support.

\section{Concerning the content of perceived peer support}

We assumed that the blind's descriptions of perceived support would be conditioned by their developmental needs, just like in the case of their peers, but also by their special needs. This assumption was confirmed for the modalities of emotional and informational support. In the case of tangible support, the special needs were obviously in the foreground.

Qualitative analysis of their responses about peer support demonstrated that the blind youth accepted it unwillingly, while realizing that their sighted pears did not know how to provide it to them. A reason for this can be found in the fact that blind and sighted peers had not grown up together, given that all our blind respondents have finished elementary school in segregated conditions.

\section{Concerning the intersection of identity crisis and the level of peer support}

We assumed that the intensity of identity crisis correlates significantly with the level of particular modalities of perceived peer support in the experimental group because peer support, aside from having other positive effects, probably contributes to the overcoming of conflicts between environmental demands and the young blind's abilities to cope with them. The correlations we obtained do not allow us to state anything about causal links and our thinking is, therefore, purely hypothetical.

We mentioned some studies which demonstrated that peer support to visually impaired adolescents was a significant predictor of high self-esteem, less loneliness, high well-being and good adjustment. Our results also underlined the importance of peer support to the blind, but not any kind of support. Namely, only the correlation of the identity crisis score with tangible support score is significant in the experimental group. The negative correlation $(\mathrm{r}=-.0 .397)$ may mean that this type of support was significantly missing in the young blind during the crisis. This is proved by the finding that the arithmetical mean was lowest for tangible peer support to the blind (Table 2). What lies at its basis is probably a conflict between the developmental need for independence and the need for tangible support - a conflict that is characteristic of blind adolescents. This conclusion is supported by the finding that the calculated correlations between the intensity of identity crisis and tangible peer support (and other modalities of support) in the control group were not significant. 


\section{Conclusion}

Our study has demonstrated that the young blind, when compared to their sighted peers, experience much more strongly their identity crisis. There were more blind adolescents experiencing a delayed crisis than sighted ones. This can be explained by the fact that delayed attachment process, inadequate practical-social communication, parental overprotection, poor experiences with peers, lack of stimulation for social development, absence of reciprocal and egalitarian relationships with peers and other factors produce in the young blind a series of conflicts the resolution of which demands comparatively more time. Aside from analyzing the factors that contribute to the emergence of identity crisis in the blind, future research should pay attention to the strategies and resources of its overcoming. Analysis of the characteristics of the young who do not present indicators of identity crisis and of those who have successfully overcome it before the age of 21 years would provide a basis for the creation of programs of prevention of delayed identity crisis.

One of our findings is that all forms of support were significantly weaker in the experimental than in the control group. This probably represents an effect of prejudices, stigmatization and discrimination. We were surprised by the fact that even tangible peer support was weak (even the weakest), although the need for this type of support is heightened. Even more important was the fact that only the correlation of the identity crisis score with tangible peer support score is significant in the group of the blind. Our data suggest that this kind of support was missing during the crisis. This is perhaps reinforced by a conflict between the developmental need for independence and the young blind's need for tangible support.

Qualitative analysis revealed that the contents of informational and emotional supports were similar in the sighted and the blind, while the content of tangible support was very different, which means that development needs of all are the same, but in the case of tangible support it seems that developmental needs are blocked by special needs that are more basic for the blind. Moreover, the analysis of their responses about peer support demonstrated that they accepted it unwillingly, while realizing that their sighted pears did not know how to provide it to them. One of the possible reasons is that our blind respondents did not have much opportunity to socialize with their sighted peers while at elementary school, because they were schooled in segregated conditions. Future studies should test the restricting effect of this factor on perceived and received peer support.

One of the limitations of this study is that the assessment of the level of perceived peer support was carried out through one item only, in the form of a threepoint assessment scale, for each support modality. This has prevented us from carrying out a more sophisticated statistical analysis in order to test whether the level of peer support is a predictor of the intensity of identity crisis. This assumption should 
be tested in future studies that would make use of Procidano and Heller's PSS-Fr (1983, according to Chronister, Johnson \& Berven, 2006), the Berlin Social Support Questionnaire (Schwarzer \& Schulz, 2000, according to Pinquart \& Pfeiffer, 2011) or some other scale of assessment of perceived social peer support.

\section{REFERENCES}

Beaty, L. A. (1991). The effects of visual impairment on adolescent's self-concept. Journal of Visual Impairment \& Blindness 85 (3): 129-130.

Beaty, L. A. (1992). Adolescent self-perception as a function of vision loss. Adolescence 27 (107): 707-714.

Chapman, E. (1978). Visually handicapped children and young people. London, Henley, Boston: Routledge and Kegan Paul.

Celeste, M. \& Kobal Grum, D. (2010). Social integration of children with visual impairment: A developmental model. Elementary education online 9 (1): 11-22.

Chronister, J. A., Johnson, E. K., \& Berven, N. L. (2006). Measuring social support in rehabilitation. Disability and rehabilitation 28 (2): 75-84. doi: 10.1080/09638280500163695

Cimarolli, V.R. (2006). Perceived overprotection and distress in adults with visual impairment. Rehabilitation psychology 51 (4): 338-345. doi: 10.1037/0090-5550.51.4.338

Cimarolli, V.R., Reinhardt, P.J., \& Horowitz, A. (2006). Perceived Overprotection: Support Gone Bad? The Journals of Gerontology: Series B 61 (1): 18-23.

Colarossi, L.G \& Eccles, J.C. (2000). A prospective study of adolescents' peer support: Gender differences and the influence of parental relationships. Journal of Youth and Adolescence 29 (6): 661-678. doi: 10.1023/A:1026403922442

Cotterell, J. (1996). Social networks and social influences in adolescence. London: Routledge.

Erikson, E. H. (1979). Identity, Youth, and Crisis. New York: W. W. Norton.

Feldman, S.S. \& Quatman, T. (1988). Factors influencing age expectations for adolescent autonomy: A study of early adolescents and parents. The Journal of Early Adolescence 8 (4): $325-$ 343.

Fraiberg, S. (1977). Insights from the Blind. New York: Basic books.

Freeman, H. \& Brown, B.B. (2001). Primary attachment to parents and peers during adolescence: Differences by attachment style. Journal of Youth and Adolescence 30 (6): 653-674. doi: 10.1023/A:1012200511045

Golombek, H. \& Marton, P. (1992). Adolescents over time: A longitudinal study of personality development. Adolescent Psychiatry 18 (1): 213-284.

Hall, L. J. \& McGregor, J. A. (2000). A follow-up study of the peer relationships of children with disabilities in an inclusive school. Journal of Special Education 34 (3): 114-126. doi $10.1177 / 002246690003400301$

Head, D. (1979). A Comparison of self-concept scores for visually handicapped adolescents in several class settings. Education of the Visually Handicapped 10: 51-55. 
Huijgevoort, T.V. (2002). Coping with a visual impairment through self-investigation. Journal of Visual Impairment and Blindness 96 (11): 783-795.

Huurre, T. M., Komulainen, E. J., \& Aro, H. M. (1999). Social support and self-esteem among adolescents with visual impairment. Journal of Visual Impairment \& Blindness 93 (1): 26-37.

Huurre, T. \& Aro, H. (2000). The psychosocial well-being of Finnish adolescents with visual impairments versus those with chronic conditions and those with no disabilities. Journal of Visual Impairment \& Blindness 94 (10): 625-637.

Ihsen, E., Troester, H., \& Brambring, M. (2010). The role of sound in encouraging infants with congenital blindness to reach for objects. Journal of Visual Impairment \& Blindness 104 (8): 478488.

Kef S. (1997). The personal networks and social supports of blind and visually impaired adolescents. Journal of Visual Impairment and Blindness 91 (3): 236-244.

Kef, S., Hox, J. J., \& Habekothe, H. T. (2000). Social networks of visually impaired and blind adolescents: Structure and effect on well-being. Social network 22 (1): 73-91. doi:10.1016/S0378-8733(00)00022-8

Kef, S. (2002). Psychosocial adjustment and the meaning of social support for visually impaired adolescents. Journal of Visual Impairment and Blindness 96 (1): 2-37.

Kekelis, L. S. (1992). Peer interactions in childhood: The impact of visual impairment. In: S. Z. Sacks, L. S. Kekelis \& R. J. Gaylord-Ross (Eds.), The development of social skills by blind and visually impaired students: Exploratory studies and strategies. New York: American Foundation for the Blind.

King, G. A., Law, M., King, S., Rosenbaum, P., Kertoy, M. K., \& Young, N. L. (2003). A conceptual model of the factors affecting the recreation and leisure participation of children with disabilities. Physical \& Occupational Therapy in Pediatrics 23 (1): 63-90.

Klimstra, T.A., Hale III, W.W., Raaijmakers, Q.A.W., Branje, S.J.T., \& Meeus, W.H.J. (2010). Identity formation in adolescence: Change or stability? Journal of Youth and adolescence 39 (2): 150-162. doi: 10.1007/s10964-009-9401-4

Koenes, S. G. \& Karshmer, J. F. (2000). Depression: A comparison study between blind and sighted adolescents. Issues in Mental Health Nursing 21 (3): 269-279. doi: $10.1080 / 016128400248086$

Kondić, K. (1997). Daj mi pedalj zemlje pa ću svet pokrenuti. U: V. ĆurČić (Prir.) Adolescencija - revolucija i evolucija u razvoju. Beograd: IP »Žarko Albulj«. Str. 31-38.

Kroger, J. (2001). Identity in adolescence. London \& New York: Routledge.

Kroger, J. (2003). Identity development during adolescence. In: J. R. Adams \& M. D. Berzonsky (eds.) Blackwell handbook of adolescence. Malden MA: Blackwell publishing, pp. 205-225.

Laible, D.J., Carlo, G., \& Raffaelli, M. (2000). The differential relations of parent and peer attachment to adolescent adjustment. Journal of Youth and Adolescence 29 (1): 45-59. doi: 10.1023/A:1005169004882

Lappin, G. (2006). Infant massage: facilitating positive change in dyadic interactions. 12. ICEVI world conference. Kuala Lumpur. CD of full paper : 07. Early childhood intervention, nac. 033. 
Levitt, M. J., Guacci-Franco, N., \& Levitt, J. L. (1993). Convoys of social support in childhood and early adolescence: Structure and function. Developmental Psychology 29 (5): 811-818. doi: 10.1037/0012-1649.29.5.811

Lifshitz, H; Hen, I., \& Weisse, I. (2007). Self concept, adjustment to blindness and quality of friendship among adolescents with visual impairments. Journal of Visual Impairment \& Blindness 101 (2): 96-107.

Loots, G., Devisé, I., \& Sermijn, J. (2003). The interaction between mothers and their visually impaired infants: An intersubjective developmental perspective. Journal of Visual Impairment and Blindness 97 (7): 403-417.

Lopez-Gusticia, M. D; Pichardo, M. C; Amezcua, G.A., \& Fernandez, E. (2001). The self-concepts of Spanish children and adolescents with low vision and their sighted peers. Journal of visual Impairment \& Blindness 95 (3): 150-160.

Marcia, J.E. (1966). Development and validation of ego-identity status. Journal of Personality and Social Psychology 3 (5): 551-558. doi: 10.1037/h0023281

Medovy, H. (1964). Problems of adolescence. Canadian Medical Association Journal 90 (24): $1354-1360$.

Meighan, T. (1971). An investigation of the self-concept of blind and visually handicapped adolescents. New York: American Foundation for the Blind.

Moshman, D. (2005). Adolescent psychological development, rationality, morality and identity. Mahwah, New Jersey, London: Lawrence Erlbaum ssociates.

Murugami, M. (2009). Disability and identity. Disability studies quarterly 29 (4) www.dsqsds.org/article/view/979/1173 retrieved on 17.12.2010.

Offer, D. \& Offer, J. (1975). From Teenage to Young Manhood. New York: Basic Books.

Offer, D. \& Schonert-Reichl, K. A. (1992). Debunking the myth of adolescence: Finding from recent research. Journal of the American Academy of Child and Adolescent Psychiatry 31 (6): 1003-1014.

Opperman, S. \& Alant, E. (2003). The coping responses of the adolescent siblings of children with severe disabilities. Disability and Rehabilitation 25 (9): 441-454.

Papadopoulos, K., Metsiou, K., \& Agaliotis I. (2011). Adaptive behavior of children and adolescents with visual impairments. Research in Developmental Disabilities 32 (3): 1086-1096.

Pinquart, M. \& Pfeiffer, J.P. (2011). Associations of extroversion and parental overprotection with forming relationships with peers among adolescents with and without visual impairments. Journal of visual impairment \& blindness 105 (2): 96-107.

Recchia, S. L. (1997). Play and concept development in infants and young children with severe visual impairments: A constructivist view. Journal of Visual Impairment \& Blindness 91 (4): 401407.

Robinson, B. L. \& Lieberman L. J. (2004). Effects of visual impairment, gender, and age on selfdetermination. Journal of Visual Impairment \& Blindness 98 (6): 351-366.

Roch-Levecq, A. C. (2006). Production of basic emotions by children with congenital blindness: Evidence for the embodiment of theory of mind. British Journal of Developmental Psychology 24 (3): 507-528.

Rosenblum, P. (1998). Best friendships of adolescents with visual impairments: A descriptive study. Journal of Visual Impairment \& Blindness 92 (8): 593-608. 
Rosenblum, P. (2000). Perceptions of the impact of visual impairment on the lives of adolescents. Journal of Visual Impairment \& Blindness 94 (7): 434-445.

Sandberg, A., Björck-Ĺkesson, E., \& Granlund M. (2004). Play in retrospection: Play experiences from childhood in adults with visual disability, motor disability and Asperger syndrome. Scandinavian Journal of Disability Research 6 (2): 111-130.

Sk?r, L. (2003). Peer and adult relationships of adolescents with disabilities. Journal of Adolescence 26 (6): 635-649.

Stanimirović, D. (2007). Psychological support system of blind adolescents and youth. In: B. Eškirović \& V. Vučinić (eds.) Transition of special education and rehabilitation - New possibilities. Belgrade: University of Belgrade, Faculty of Special Education and Rehabilitation, pp. 519-526.

Stewart, S. M., Bond, M. H., Mcbride-Chang, C., Fielding, R., Deeds, O., \& Westrick, J.(1998). Parent and Adolescent Contributors to Teenage Misconduct in Western and Asian High School Students in Hong Kong International Journal of Behavioral Development 22 (4): 847869.

Warren, D. (1994). Blindness and children - an individual differences approach. Cambridge: University Press.

Waterman, A.S. (1982). Identity development from adolescence to adulthood: An extension of theory and a review of research. Developmental Psychology 18 (3): 341-358.

Wilkinson, R.B. (2004). The role of parental and peer attachment in the psychological health and self-esteem of adolescents. Journal of Youth and Adolescence 33 (6): 479-493. doi: 10.1023/B:JOYO.0000048063.59425.20

Wolffe, K. (2000). Focused on: Social Skills for Teens and Young Adults with Visual Impairments. New York: American Foundation for the Blind. 
Драгана В. Станимировић

Сажее̄⿲ак

Факултет за специјалну едукацију и рехабилитацију

Универзитет у Београду

Лука Р. Мијатовић

Факултет за специјалну едукацију и рехабилитацију

Универзитет у Београду

Сања М. Димоски

Факултет за специјалну едукацију и рехабилитацију

Универзитет у Београду

\section{КРИЗА ИДЕНТИТЕТА СЛЕПИХ АДОЛЕСЦЕНАТА И ЊИХОВ ДОЖИВљАЈ ПОДРШКЕ КОЈУ ИМ ПРУЖАЈУ ВРШЊАЦИ}

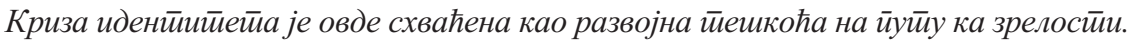

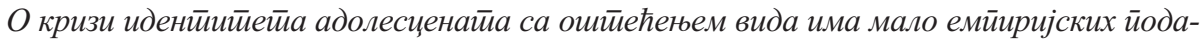

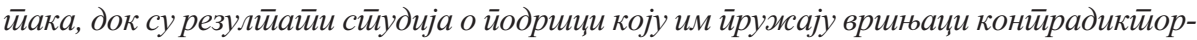
ни. То нас је мойивисало да уйоредно исииийамо кризу иденииийейа код слейих адолесценайа И вршьака који виде. Такође смо желели да, користиећи комйарайивну анализу, дамо доиринос бољем разумевању йодрике коју им врињаци ирружају И йовеза-

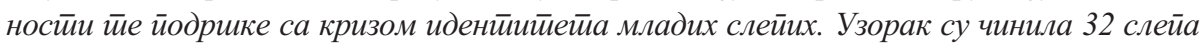
И 32 адолесценӣа конитролне іруйе. Подайке смо йрикуйили йуиеем иниеервјуа И листие индикайора кризе иденйииетйа. Резулйайи су йоказали да слейи адолесцениии у

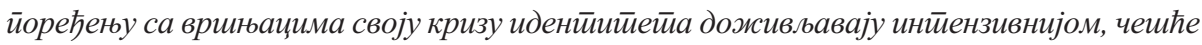
одложеном, док за сва йри облика йодршке вршњака дају ниже йроцене. Садржаји ойажене емоционалне И информационе йодрике врињака су слични, а садржаји ойажене конкрейне йодрике врињака значајно су различитии у исиииииваним іруйама. Показало се да је једина значајна корелација између ойажене конкрейне йодрике врињака И кризе иденйийейа у іруиии слейих адолесценайа. Дакле, налази указују на нарочий значај конкреӣне ӣодрике вршњака за слейе адолесценйе.

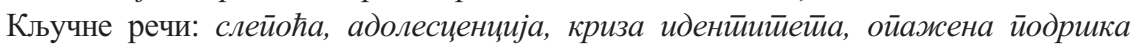
врињака 